\title{
XLIII. Memoir on the urao (Carbonate of Soda)
}

\section{Messr Mariano de Rivero \& Messr J.B. Boussingault}

To cite this article: Messr Mariano de Rivero \& Messr J.B. Boussingault (1825) XLIII. Memoir on the urao (Carbonate of Soda), Philosophical Magazine Series 1, 66:330, 278-279, DOI: $10.1080 / 14786442508673966$

To link to this article: http://dx.doi.org/10.1080/14786442508673966

曲 Published online: 10 Aug 2009.

Submit your article to this journal

Џ Article views: 2

Q View related articles $\sqsubset$ 
XLIII. Memoir on the Urao (Carbonate of Soda). By Mess's. Mariano de Rivero and J. B. Boussingault *

TO the south-west of Merida, and at one day's journey from this city, in the direction of La Grita, is a small Indian village, called Lagunillas, on account of its being situated at a short distance from a lake, whence the aborigines have extracted for a great number of years past a kind of salt called Urao.

The lake is about 3281 feet long and 820 wide. Its greatest depth is not quite ten feet. It is situated in a clayey soil containing large fragments of a secondary freestone. By a barometrical observation we have made, it appears to be 3323.65 feet above the level of the sea. In order to obtain the urro, the Indians make under the water an excavation of several yards in extent, in which they place a pole, from 14 to 16 feet long, the top of which projects above the water. This being done, an Indian leaning on the first pole directs another towards the bed of salt at a certain angle. On this pole a second Indian immediately slides down, dives, and after a few minutes spent under the water returns with some fragments of the salt. According to the information we have received, there is previous to reaching the urao, the bed of which is not very thick, about a yard of mud and a bed containing many crystals of carbonate of lime. The water of the lake is but slightly saline, and animals drink it with avidity.

The urco is crystallized in prismatic needles which appear to diverge from a common centre; it has a glassy aspect; its hardness is rather less than that of carbonate of lime; its taste alkaline, and similar to that of carbonate of soda; it does not effloresce on exposure to the air. We pass over the details of the analysis, and only give the results:

Carbonic acid 0.3900 Water . . . . . . . . 0.1880

Soda . . . 0.4.122 1 Foreign substances and loss 0.0098

This salt therefore contains more carbonic acid than the carbonate, and less than the bi-carbonate. The carbonate of soda called Trona, analysed by Klaproth, and which came from the province of Sukena, near Fezzan in Africa, has much analogy with the urao. The following are the results obtained from it by the chemist of Berlin,

Carbonic acid .... 0.3900

Soda . . . . . . 0. 0.3800

Water........ 0. 0.2300

* From Annales de Chimie, tom. xxix. p. 110; originally published in Spanish, at Bogota.

The 
Mr. Haworth's Fifth Decade of new Succulent Plants. 279

The urao salt is used in the country as a kind of mordant to an extract of tobacco, which, when held in the mouth, produces a secretion of saliva: this preparation is called chimo or moo. At Merida they mix four arrobas of urao with eight of tobacco; at Varinas the urao forms but one-fourth of the proportion of tobacco. The moo contains less urao than the chimo.

XLIV. Decas quinta novarum Plantarum Succulentarum; Autore A. H. Haworth, Soc. Linn. Lond. -Soc. Horticult. Lond.-necnon Soc. Cas. Nat. Cur. Mosc. Socio, \&c. \&c.

To the Editor of the Philosophical Magazine and Journal. Sir,

A FIFTH Decade of new Succulent Plants I have hereunder the pleasure of adding to those you have already been pleased to publish in your useful and scientific Magazine.

Some of these new plants are very remarkable ones, and they are all of the Aloëan family; all recently received from that inexhaustible mine of succulent plants the Cape of Good Hope; and were all detected there in truly native wilds, by that successful explorer of those arid regions Mr. Bowie; who safely transmitted them to our gracious sovereign's unrivaled gardens at Kew, where they are now flourishing, and scarcely seem to miss their warm and native skies.

Three of these plants with remote alternate sheathing leaves are said to have red, or yellow neat flowers; and one of these, which bloomed at Kew, is reported to have had porrected stamens; which character, combined with the remote and alternate habit of the leaves, may perhaps lead to the future construction of a new genus:-nevertheless, I consider the leaves of all Aloëan plants as actually alternate, although from their usually compacted aggregation seldom offering ocular demonstration of their being so. Those of many arborescent and other Semperviva, and likewise of the Mesembryanthema capitata, I know to be alternate: and they are quite as densely crowded, and after the same manner, prior to the production of flowers; as very gradually appears by their method of evolving their bracteate inflorescence.

I remain, sir, yours, \&c.

Queen's Elm, Chelsea, Sept. 9, 1825.

A. H. Haworth.

Classis et Ordo. Hexandrip Monogynia.

Genus, Aloe Linn., Duval, \&c.-Nob. in Philosoph. Mag. Octob. 1824. 